\title{
IMPLEMENTATION OF SHARIA BANKS' SOCIAL FUNCTION AND THE IMPACT ON WELFARE OF PADANGSIDIMPUAN SOCIETY
}

\author{
Nofinawati \\ Lecturer of Sharia Banking, Islamic Business and Economy Faculty, \\ IAIN Padangsidimpuan \\ Email: nofinawati82@gmail.com
}

\begin{abstract}
Social function of Sharia Banks is to receive funds i.e. zakat, infaq, sedekah, wakaf, hibah, and distribute them in accordance to sharia laws under the banks' name or amil zakat institutions appointed by the government. This function is an aspect that distinguishes sharia banks and conventional ones. In sharia law, social function and other functions cannot exist without the other. The implementation of social function in Kota Padangsidimpuan is in accordance with legal basis which is UU No. 21 tahun 2008. However, PT. Bank SUMUT Syariah KCS Padangsidimpuan has no authority to distribute social fund due to its existence as Islamic Windows. The implementation actually has positive impact on the welfare of the society despite being temporary. While it is only impactful towards those who receive the fund, the distribution is helpful.
\end{abstract}

\section{Keywords : aplication, social function, sharia banking, falah}

\section{INTRODUCTION}

Due to its social function, sharia bank is obliged to receive social fund i.e. zakat, infaq, sedekah, wakaf, hibah and distribute them in accordance to sharia laws under the banks' name or amil zakat institutions appointed by the government. ${ }^{1}$ As elaborated in legal basis which is UU No. 21 tahun 2008, chapter II, article 4, point 2 stated below: ${ }^{2}$

- Sharia banks and Islamic Windows must collect and distribute fund.

- Sharia banks and Islamic Windows can implement the social function in a form of Baitul Mal institution, which is receive fund collected from zakat, infaq, sedekah, hibah, or other social fund and distribute them to Amil Zakat institutions.

- Sharia banks and Islamic Windows can collect social fund from money waqf and distribute it to waqf management institutions (nadzir) as the will of the one who gives waqf (wakif).

- The implementation as mentioned in point (2) and point (3) is in accordance with law and regulations.

Social function distinguishes sharia banks and conventional banks. In sharia banks, one function cannot exist without the other, which is a special trait. In the arrangement of Kerangka Dasar Penyusunan dan Penyajian Laporan Keuangan Syariah (KDPPLKS) published by Ikatan Akuntan Indonesia (IAI), one of the elements in a sharia bank's financial statement is a component containing banking activities based on sharia laws. The component consists of reports on the sources and the distribution of zakat funds, as well as reports on sources and the distribution of benevolent funds. ${ }^{3}$

\footnotetext{
${ }^{1}$ Wiroso, Penghimpunan Dana \& Distribusi Hasil Usaha Bank Syariah, (Jakarta: PT. Grasindo,2005), pg. 18.

${ }^{2}$ UU No.21 Tahun 2008 concerning sharia banking.

${ }^{3}$ Muhammad, Manajemen Bank Syariah, (Yogyakarta : UPP AMPYKPN, 2005), pg.346.
} 
As we conduct an observation on sharia banks' official websites and the websites of ojk.go.id, they have no longer published reports on the sources and the distribution of zakat funds as well as reports on sources and the distribution of qardhul hasan fund. This is contrast to the fact that the publishing of two afore mentioned reports are compulsory in order to assess the performance of sharia banks.

Because of the missing reports, it is as if the social activities of sharia banks were simply ignored. The initial establishment of sharia banks such as Mit Ghamr in Egypt is to carry out activities engaged in services for the people in poverty living in countryside. They focus on economic development, poverty alleviation, and educating them to scrimp to people living poorly. It is strange that the orientation of sharia banks is indoctrinated as to gain maximum profit. As a result, the banks can only provide services for the rich or those who possess a pricey collateral.

In Indonesia, sharia banking has been growing rapidly over the past years. The increase of offices has reached 1.869 units and the labor has reached 51.110 personnel. The growth is supported by intermediary function of banking which reaches level as much as $85.99 \%$ by the end of 2016. ${ }^{4}$ It shows that the chance of intermediary function to drive the economy is high. Nevertheless, the growth is not spread evenly in every corner of Indonesia. Business practice that emphasizes more on profit oriented has caused gap in the poor in utilizing sharia product. According to Statistics of Sharia Banks (December, 2016) the distribution of fund is still dominated by murabahah as much as IDR 110.063 billion (61.8\%) followed by profit-losssharing financing at IDR 62.151 billion (34.92\%), Qardh at IDR 3.883 billion (2.18\%), Ijarah at IDR 1.883 billion (1.06\%), and Istishna at IDR 25 billion (0.014\%)

From the data it can be inferred that the distribution of qardh is still few compared to murabahah. Whereas the social fund of sharia banks can be one of the sources to fund consumptive and productive for the poor as well as fund start-up business carried out by students. If the source comes from zakatand there is problem in the future, it will not cause a financial distress.

According to initial survey carried out on the residents of Kota Padangsidimpuan, they have not yet to experience the implementation of sharia banks' social function. Mrs. Halimah who resides on the neighborhood of PT Bank Syariah Mandiri Padangsidimpuan Branch Office claims that even as a small-scale business owner she has never received distribution of funding from aforementioned bank. ${ }^{5}$

This research is conducted based on the elaborated backgrounds above. It aims to figure out the implementation of social function and its impact on the welfare of people around Kota Padangsidimpuan.

\section{THEORETICAL REVIEW}

\section{Literature Review}

\section{- Functions of Sharia Bank}

The experts emphasize that banking holds a position to mediate in financing as well as intermediate those who possess excess amount of fund (surplus fund) and those who need them (deficit fund). It is due to the fact that bank collect fund from its customers and distribute them to those in need. Other than as finance mediation, bank also has a role to offer services such as transfer, incaso, clearing, etc. ${ }^{6}$

\footnotetext{
${ }^{4}$ www.ojk.go.id, Accessed on October 15th 2017.

5 Interview on Mrs. Halimah, in Padangsidimpuan on September $16^{\text {th }}, 2017$.

6Wiroso, Produk Perbankan Syariah, (Jakarta : LPFE Usakti, 2009), pg. 81.
} 
Meanwhile sharia bank has functions as follows:

- Investment Manager

As investment manager, sharia bank collects fund from investors under sharia principle such as wadi'ah yad dhamanah (deposit), mudharabah (profit/loss sharing), or ijarah (rent). In other words, sharia bank has a role as depositor's (shahibul maal) investment manager. The amount of return on investment depends on the result of sharia bank in managing the fund.

- Investor

As an investor, sharia bank distributes fund through financing under profit/loss sharing principle (mudharabah and musyarakah), ijarah (ijarah and ijarah muntahia bittamilik) as well as the principle of buying and principle (murabahah, salam, and istishna). As an investor, sharia bank has to distribute the fund towards productive sectors with minimum risk. In other words, this function is closely related to the other function of sharia bank as investment manager. ${ }^{7}$

- Banking Service

Sharia banks provides financial service, non-financial service, and agency service. Financial service includes financing under the principle of wakalah (mandate), kafalah (bank guarantee), hiwalah (debt transfer), rahn (mortgage), qardh (benevolent loan for bailout), sharf (buying and selling foreign currency), etc. Nonfinancial service is offered in the form of safe deposit boxes and agency services under mudharbah muqayyadah principle. ${ }^{8}$

\section{- Social Function}

In a concept of sharia banking, bank is entailed to provide social services through qard fund (benevolent loan) or zakat, infaq, shadaqah as well as other donation funds in accordance with Islamic principle. ${ }^{9}$

From the functions above, social function is also what distinguishes sharia bank from conventional bank. Even though social activities are carried out in conventional bank, it is only done by individuals who is well-aware about social-related topic.

\section{- Social Function of Sharia Bank}

\section{- $\quad$ Source and Utilization of Qardhfund}

The word Qardh derives from Arabic term qiradh that means 'to cut'. It is due to the fact that the welfare of debtor is cut and then given to creditor. ${ }^{10} Q a r d h$ is a process to grant property to another person who can be billed in the future; or in other words, lending without expecting compensation. In classical Fiqh literature, qardh is categorized in a tathawwui contract (a contract that helps each other but not in a commercial-transaction manner). ${ }^{11}$

According to Ascarya, Qardh is benevolent / non-rewarding benevolent loan, usually used for the purchase of fungible goods (i.e. items that can be estimated and replaced according to weight, size and amount). ${ }^{12}$ Qardh funding sources can come from internal and external sharia banks. Qardh sources of funds that originates from external banks come from infaq funds, alms, endowments and the likes, as well as

${ }^{7}$ Wiroso, Penghimpunan Dana dan Distribusi Hasil Usaha Bank Syariah, Op. Cit, pg. 10

${ }^{8}$ Veithzal Rivai, Bank and Financial Institution Management (Conventional dan Sharia System), (Jakarta: PT. Raja GrafindoPersada, 2007),pg. 765

${ }^{9}$ Wiroso, Produk Perbankan Syariah,0p. Cit., pg. 86

${ }^{10}$ Sutan Remy Sjahdeini, Perbankan Syariah : Produk-Produk dan Aspek Hukumnya, (Jakarta : Kencana, 2014), pg.342

11 M. NurRianto al Arif, Dasar-dasar Pemasaran Bank Syariah, (Bandung : Alfabeta, 2012), pg.56

${ }^{12}$ Ascarya, Akad dan Produk Bank Syariah, ( Jakarta : Rajawali Pers, 2011), pg. 46 
non-halal funding sources. While the source of qardh funds originating from the bank is taken from the bank's equity (capital). ${ }^{13}$

According to PSAK No. 101 point 75, the source of benevolent funds consists of: infaq, alms, the results of the management of waqf in accordance with the applicable law, the return of productive virtue funds, fines, non-halal income, donations/grants. Whereas according to DSN Fatwa No. 19 / DSN-MUI / IV / 2001 the source of Dana alQardh are as follows: ${ }^{14}$

a. Part of the capital of LKS; this fund is usually used for short-term bailout funds to customers who have deposits in sharia banks.

b. Profits of LKS that is on hold; this fund is used for social assistance

c. Other institutions or individuals who entrust the distribution of infaqto LKS. This fund is used to provide financing to hawkers or small traders. ${ }^{15}$

\section{- $\quad$ Source and Utilization of Zakat}

Zakat is a certain part of the assets that must be paid by the zakat payer (muzakki) to be handed over to the recipient of zakat (mustahiq). The payment of zakat is done if the Nisaband haul are fulfilled from the assets that meet the criteria for compulsory zakat. Basically, the obligation of zakat is shahibulmaal. The bank has to play their role as amilzakat. ${ }^{16}$

Sources of zakat comes from banks and other parties received by the bank to be distributed to those who are entitled to receive zakat. The utilization of zakat in the form of distribution to people who are entitled to receive zakat in accordance with sharia principles. They are such as the poor, slaves, debt-laden people, converts, $f i$ sabilillah, ibnusabil and amil as instructed in Surah At-Taubah verse 60 quoted below:

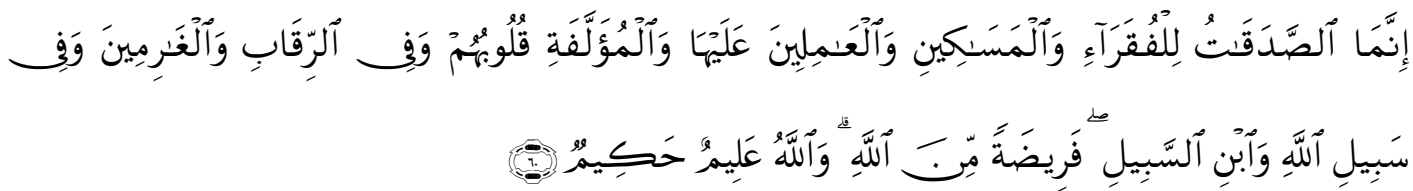

Translation:

Zakah expenditures are only for the poor and are employed to collect [zakah] and for bringing hearts together [for Islam] and for freeing captives and for those in debt and for the cause of God and for the [stranded] traveler - an obligation [imposed] by Allah. And Allah is Knowing and Wise. (Q.S. At-Taubah:60)

From the verse above, it can be inferred that the people entitled to receive zakat are as follows:

a. Fakir: people who are very miserable because they do not own any assets and means to fulfill their livelihood

b. Miskin: people whose daily income cannot fulfill their livelihood and is in a state of deprivation

c. Amil Zakat: people who collect and distribute zakat.

d. Muallaf: people who have recently converted to Islam whose faith is still weak as well as non-believers who hope to convert into Islam.

\footnotetext{
${ }^{13}$ Pedoman Akuntansi Perbankan Syariah Indonesia (PAPSI) Tahun 2003.

14Fatwa DSN No 19/DSN-MUI/IV/2001 concerning al-Qardh

15 Ismail, Perbankan Syariah, (Jakarta : Kencana, 2011), pg. 213.

${ }^{16}$ Slamet Wiyono, Cara Mudah Memahami Akuntansi Perbankan Syariah Berdasarkan PSAK dan PAPSI, (Jakarta : PT. Grasindo, 2006), pg. 173.
} 
e. Slaves: slaves and muslims who are held captive by non-believers.

f. Sabilillah; people who fights in favor to Allah in order to defend Islam and Muslims. Some mufasirinargue that the fisabilillah includes general deeds such as establishing schools, hospitals, and others related to good deeds.

g. People who are in the midst of the quest and are in deep misery in the process.

\section{- The Impact of Implementation of Sharia Banks's Social Function on Society Welfare}

Qardh benefits the society and sharia banks themselves. Those benefits are mentioned below: ${ }^{17}$

- Assisting customers in times of difficulty by providing short-term bailouts

- Small traders get assistance from sharia banks to expand their businesses which is an implementation of social mission for sharia banks to help the poor.

- Being able to divert small traders from debt bonds with moneylenders demanding high interest by getting debts from sharia banks

- Increasing the loyalty of society to sharia banks because the banks can provide some benefits for the poor.

The four benefits of Qardh above are in accordance with the objectives of sharia banks listed in legal basis UU No. 21 tahun 2008 concerning Sharia Banking, chapter II, article 3 , that states "Sharia banking aims to support implementation of national development in order to improve justice, sense of unity, and equality of people's welfare.

Hence, it can be inferred that Islamic banks have a purpose for the welfare of society. Such goal can be achieved if the social function of Islamic banks has been implemented optimally.

\section{METHOD}

\section{Research Method}

This research is conducted by using qualitative methods because we want to describe the implementation of the social function of sharia banks and the impact on the welfare of society around Padangsidimpuan from an informan perspective. Bogdan and Taylor define qualitative research methods as research procedures that produce descriptive data in the form of written or oral words from people and observed behavior. ${ }^{18}$

\section{Data Source}

- Primary data source; the data is obtained directly from the field based on observations and interviews on leaders and staffs of PT. Bank Muamalat Indonesia, PT. Bank Syariah Mandiri and Sharia Sumut Bank as well as the society living in Padangsidimpuan.

- Secondary data source; the data is obtained from other parties who have previously collected them in a form of notes, documentation, books, and others relevant to the research problem.

\section{Data Collection}

Data is collected by obtaining information from informants, which are:

- Observation; the researcher is the main instrument in conducting observations to collect data this research is concerned about.

\footnotetext{
17 Ismail, Op., Cit., pg. 214.

${ }^{18}$ Lexy Moleong, Metodologi Penliltian Kualitatif, (Bandung: Remaja Rosdakarya: 1989), pg. 3.
} 
- Interviews ${ }^{19}$; interviews conducted by researchers on informants are non-structural, free, and open. The purpose is to avoid reluctance, stiffness, awkwardness, or even the tendency to hide the real information due to the fear over being disseminated. ${ }^{20}$ Therefore, the language used in the interview is one the respondents are familiar with. The respondents consist of parties involved in the focus of research, which are leaders and staffs of PT. Bank Muamalat Indonesia, PT. Bank Syariah Mandiri and Bank SyariahSUMUT branch and the society in Padangsidimpuan who are considered to have knowledge and attention to the focus of research.

- Documentation; which is in the form of data regarding the implementation of social functions in the sharia banks in Padangsidimpuan.

\section{DISCUSSION AND RESULTS}

Implementation of the Social Function of Islamic Banks in Padangsidimpuan

- Implementation of Social Functions at PT. BMI (Bank Muamalat Indonesia), Tbk KCU (General Branch Office) Padangsidimpuan

Based on the results of interview with Mr. Rizky Fahlevi (Service Assistant) at PT. BMI, Tbk Padangsidimpuan KCU, it can be inferred that social function is always implemented there. Implementation of social functions at PT. BMI, Tbk is carried out by BMM (Baitul Maal Muamalat) in Jakarta. However, PT. BMI, Tbk KCU Padangsidimpuan continues to carry out social activities as an extension of BMM institutions in Jakarta. The activities based on the function are outlined below ${ }^{21}$ :

- Activities to collect and distribute zakat funds

Zakat collection activities at PT. BMI, Tbk Padangsidimpuan KCU comes from:

a) Employee salaries; $2.5 \%$ of the salaries of employees who are classified as muzakki (people who are obliged to pay zakat). It is the main source of zakat funds at PT. BMI, Tbk KCU Padangsidimpuan. The collection is deducted regularly by the system at PT. BMI, Tbk.

b) Donors; which include both customers and non-customers. Donors are those called muzakki who entrust PT. BMI, Tbk KCU Padangsidimpuan to distribute zakat to mustahik (people who are entitled to receive zakat)

c) Customers as the depositors of Tabungan Sahabat type A. The collection is under the consent of aforementioned customers before signing the contract. They are asked about the willingness to pay zakat monthly by automatically deducting a certain amount from their account.

The distribution of zakat funds at PT. BMI, Tbk Padangsidimpuan KCU consists of two types of activities, namely routine activities (without submitting proposals to the Central BMM institution) and non-routine activities (must be submitted to the Central BMM institution). Routine activities are usually held in the month of Ramadan. In the month of Ramadan PT. BMI, Tbk KCU Padangsidimpuan distribute zakat funds to: ${ }^{22}$

a) Poor people

b) Orphans

\footnotetext{
${ }^{19}$ Cik Hasan Bisri, Pilar-Pilar Penelitian Hukum Islam dan Pranata Sosial, (Jakarta: Raja Grapindo Persada, 2004$)$ pg. 292.

${ }^{20}$ Soejaono Soekamto,Pengantar Penelitian Hukum, (Jakarta: UI-Press, 1986), pg. 230.

${ }^{21}$ Interviews with RizkyFahlevi (Service Assistance) of PT. BMI. Tbk., KCU Padangsidimpuan, on July $9^{\text {th }}, 2018$.

${ }^{22}$ Interviews with Rizky Fahlevi (Service Assistance) of PT. BMI. Tbk., KCU Padangsidimpuan, on July $10^{\text {th }}, 2018$.
} 
First, the process of distributing zakat funds to the poor and poor is carried out by PT. BMI, Tbk KCU Padangsidimpuan without submitting a proposal to BMM institutions. Personnel who is responsible to implement social activities at PT. BMI, Tbk Padangsidimpuan KCU notifies the Head of the Environment (Kepling) in the area of his choice, about the distribution of zakat funds and notifies about the requirements.

The requirements are:

a) photocopy of Family Card (KK)

b) filled-out Mustahik forms approved by Kepling / Mosque Management,

c) opening an account at PT. BMI, Tbk Padangsidimpuan KCU (as a means to disburse zakat funds).

Once the assessment process is done and the candidate meets the requirement, their data is then sent to BMM institutions. The institutions will then distribute directly by depositing the amount in each mustahik account.

Second, the distribution of zakat to orphans. Based on the results of the interview with Mr. Rusdi (collateral analyst) as well as personnel in charge of implementing social activities, PT. BMI, Tbk KCU Padangsidimpuan never distributes zakat to any orphanage in Padangsidimpuan. It is due to the insecurities whether the foundation's management receive more funding than the orphans themselves and thus the goal will not be achieved. In other words, PT. BMI, Tbk KCU Padangsidimpuan lacks trust in the management of the orphanage. PT. BMI, Tbk KCU Padangsidimpuan prefers to channel it directly to orphans around the residence of each employee of PT. BMI, Tbk KCU Padangsidimpuan according to their recommendation. ${ }^{23}$

- Activities to collect and distribute qardhul hasan funds

The source of qardhulhasan funds at PT. BMI, Tbk KCU Padangsidimpuan comes from staffs, owner, and customers of the bank itself through:

a) Infaq

b) Sadaqah

c) Non-halal income (penalty for late payment of financing installments from costumer and interest from fund placements in conventional banks)

The funds are then channeled by PT. BMI, Tbk Padangsidimpuan KCU into several forms of social activities, including the following:

a) Scholarships or Education Cost Assistance for Students in Padangsidimpuan City. ${ }^{24}$

b) Educational funding and scholarships are more often given to children of nonbanking staff (i.e. drivers and Office Boy) in PT. BMI Tbk., KCU Padangsidimpuan. The assistance comes in the form of tuition fee coverage or the coverage of school-related expenses (school clothes, books, stationery and others).

c) Assistance Costs for procuring mosque facilities such as mosque cleaning facilities (MCK), facilities for digital prayer time wall clock

The distribution process is relatively similar to the distribution of zakat. The difference is that some distribution of qardhul hasan requires proposals from PT. BMI Tbk., KCU Padangsidimpuan to BMM institutions.

\footnotetext{
${ }^{23}$ Interview with Rusdi (Collateral Analyst), in PT. BMI. Tbk., KCU Padangsidimpuan, on July $11^{\text {th }, ~} 2018$.

${ }^{24}$ Interview with Rusdi (Collateral Analyst), in PT. BMI. Tbk., KCU Padangsidimpuan, on July $12^{\text {th }}, 2018$.
} 
The social activities must be reported to BMM institutions in detail, based on the type. The report consists of reports of the implementation attached with financial statements as well as documentation as evidence. ${ }^{25}$ Up till now, PT. BMI Tbk., KCU Padangsidimpuan has never distributed benevolent loans to the society in Padangsidimpuan. It has something to do with their tendency not to pay back the debts.

\section{- Implementation of Social Functions at PT. Bank Syariah Mandiri Padangsidimpuan} Branch

Based on the results of interview with Mr. Pangasian (Marketing Officer) at PT. Bank Syariah Mandiri (BSM) Padangsidimpuan Branch, social function is also implemented there. Implementation of social functions at PT. Bank Syariah Mandiri is conducted by the LAZNAS BSM institution in Jakarta. However, PT. BSM Padangsidimpuan Branch continues to conduct social activities as an extension of the LAZNAS BSM institution at the Center. ${ }^{26}$

The social activities consist of:

- Activities to collect and distribute zakat funds

The source comes from the internal and external of the bank itself. From internal, the source consists of staffs, customers and owners of the bank.5\% of the salaries of staffs who are classified as muzakki (people who are obliged to pay zakat). However, the deduction is not compulsory and will only be done under the staffs' personal consent. (Results of Interview with Mulyana Jauhari Sakti / Bag. Managing Social Activities at PT. BSM Branch Padangsidimpuan). ${ }^{27}$

From external, the source comes from non-customer donors. This donor is a muzakki who entrusts PT. BSM Padangsidimpuan Branch to distribute zakat to mustahik (people who are entitled to receive zakat).

The distribution of zakat funds at PT. BSM Padangsidimpuan Branch consists of two types of activities, namely activities without proposals and activities that are required to submit proposals. ${ }^{28}$ Activities without proposals are as follows:

a) Distribution of zakat funds for the poor

b) Distribution of zakat funds to orphans

The process of distributing zakat funds to the poor is carried out by PT. BSM Padangsidimpuan Branch without submitting a proposal to the LAZNAS BSM institution. Likewise with the distribution of zakat funds to orphans, personnel in chargeof social activities at PT. BSM Branch of Padangsidimpuan chooses the Orphanage that will be the target of zakat funds distribution.Then, the list of targeted orphans is also recorded before being sent to LAZNAS BSM Institution. When the approval is finished, PT. BSM Padangsidimpuan Branch distributed directly to orphans in the chosen orphanage.

- Activities to collect and distribute qardhul hasan funds

Collection of qardhul hasan funds at PT. BSM Padangsidimpuan Branch comes from: ${ }^{29}$

a. Infaq

\footnotetext{
${ }^{25}$ Interviews with RizkyFahlevi (Service Assistance) of PT. BMI. Tbk., KCU Padangsidimpuan, on July $13^{\text {th }}, 2018$

${ }^{26}$ Interview with Pangasian (Marketing Officer), in PT. BSM Cabang Padangsidimpuan, on July 23 ${ }^{\text {rd }}, 2018$

${ }^{27}$ Interview with Mulyana Jauhari Sakti (CSRstaff), in PT. BSM Cabang Padangsidimpuan, on July 24 $4^{\text {th }}, 2018$

${ }^{28}$ Interview with MulyanaJauhariSakti (CSRstaff), in PT. BSM Cabang Padangsidimpuan, on July $25^{\text {th }}, 2018$

${ }^{29}$ Interview with Pangasian (Marketing Officer), in PT. BSM Cabang Padangsidimpuan, on July $26^{\text {th }}, 2018$
} 


\section{b. Sadaqah}

c. Non-halal income such as late fees for payment of financing instalments and interest from fund placements in conventional banks.

The funds collected above are distributed by PT. BSM Padangsidimpuan Branch into several forms of social activities, including the following: ${ }^{30}$

- Scholarship or Education Cost Assistance for Students and Students in Padangsidimpuan City. The scholarship is aimed towards an outstanding student and the family's economy must meet a certain criteria.

- Qurban in areas uncovered by Qurban meat such as in Napa and Pintu Padang.

- Assisting to cover the cost of renovation for mosque construction or mosque facilities. The mosque management is required to make a proposal consists of a letter of application, the SK of the Management and the Committee for Construction of the Mosque, the estimation budget, and proof of ownership by local community as well as documents needed.

Qardhul Hasan's fund distribution process is almost the same as the distribution of zakat funds above, because the process of distributing benevolent funds or qardhul hasan funds is without proposals and some must go through a proposal from PT. BSM Padangsidimpuan Branch to LAZNAS BSM institution. The proposal can be submitted online and offline by directly send it to the office branch of nearby BSM.

The social activities carried out by PT. BSM Branch of Padangsidimpuan must be reported regularly to LAZNAS BSM Institution. The reports consist of the report of implementation of social activities with evidence and documentation attached in no later than 2 weeks after the implementation. The activities are also required to be uploaded in social media and newspaper for public exposure.

Up until now, PT. BSM Padangsidimpuan Branch never distributes qardhul hasan funds to the society in Padangsidimpuan due to the characteristic of the people themselves. They assume that if they are given a benevolent loan, then they are not obliged to pay it back. The distribution in a form of virtue loans is only carried out by the central BSM Office in Jakarta.

\section{- Implementation of Social Functions at PT. Bank SUMUT Syariah KCS Padang- sidimpuan}

Based on the interviews with Mr. Ahmad Muhajid (Operational Head), it can be inferredthat the implementation of social function at this bank is carried out by the official Amil Zakat Institute (LAZ) appointed by the central Bank SUMUT Syariah in Medan. ${ }^{31}$ The branch in Padangsidimpuan only has the authority to collect social funds in the form of infaq and other benevolent funds. They are not authorized to channel the funds. Social funds collected from zakat comes from $2.5 \%$ of the staff salary.

According to Ms. Soraya (a staff), 2.5\% cut for zakat is compulsory. When natural disaster occurs, each staff also contribute in the form of infaq and shadaqah for the victims. ${ }^{32}$

In case PT. Bank SUMUT Syariah KCS Padangsidimpuan wants to distribute social funds, they take the funds from operational funds at the branch office or collect donations from staffs.

\footnotetext{
${ }^{30}$ Interview with Pangasian (Marketing Officer), in PT. BSM Cabang Padangsidimpuan, on July $27^{\text {th }}, 2018$

${ }^{31}$ Interview with Ahmad Muhajir (Operational Head), in PT. Bank SUMUT Syariah KCS. Padangsidimpuan, onJuly $16^{\text {th }}, 2018$

32 Interview with Soraya (staff), in PT. Bank SUMUT Syariah KCS. Padangsidimpuan, on July $19^{\text {th }}, 2018$
} 


\section{Impact of Implementation of Social Functions in Sharia Banking to Padangsidimpuan Society's}

According to Mr. Marwan, Mrs. Asnaini, and Mrs. Emma (some residents in Padangsidimpuan), the implementation of the sharia bank's social function has a positive impact on the society's welfare. People who initially have financial problems prior the assistance from sharia banks find it helpful to receive some fund. However, the impact is only temporary. ${ }^{33}$ Accoding to Mr. Pangasian (Marketing Officer of PT. BSM Padangsidimpuan Branch), there was an incident when the society held a demonstration in front of the branch office because they did not receive social fund while they claimed they were entitled to be the target. The case occurred during the aftermath of the flood disaster in Padangsidimpuan. The branch office finally conducted a survey and demanded data of the entitled society from the Head of Environment Sector. Afterwards, they distributed aid based on the data provided. ${ }^{34}$

Moreover, from the interview with Ms. Yusni, a member of society, she claims that she was one of the people who attended the demonstration protest. She felt to be an entitled target due to her condition being a widow. It turns out that the widow who could be entitled to receive the aid has to be the one who is poor. ${ }^{35}$

\section{CONCLUSION}

Taking the results into consideration, we can infer that the implementation of social function of sharia banks in Padangsidimpuan has been carried out in accordance with legal basis concerning sharia banking, which is UU No. 21 tahun 2008. As revealed by the result, there is a sharia bank in Padangsidimpuan which has no authority to channel social funds because its form is still Islamic windows. The implementation of social functions has positive impact on the society welfare despite temporary and only some part of the society has privilege to experience it. Regardless, they still find that the distribution of zakat and benevolent funds very helpful.

\section{REFERENCES}

Ascarya, Akad dan Produk Bank Syariah, Jakarta : Rajawali Pers, 2011.

Cik Hasan Bisri, Pilar-Pilar Penelitian Hukum IIslam dan PranataS osial, Jakarta: Raja Grapindo Persada, 2004.

Fatwa DSN No 19/DSN-MUI/IV/2001tentangal-Qardh.

Ismail, Perbankan Syariah, Jakarta: Kencana, 2011.

Khaerul Umam, Manajemen Perbankan Syariah, Bandung: Pustaka Setia, 2013.

Lexy Moleong,Metodologi Penliltian Kualitatif, Bandung: Remaja Rosdakarya: 1989.

M. Nur Rianto al Arif, Dasar-dasar Pemasaran Bank Syariah, Bandung: Alfabeta, 2012.

Muhammad, Manajemen Bank Syariah, Yogyakarta: UPP AMPYKPN, 2005.

\footnotetext{
${ }^{33}$ Interview with Marwan (a society member), in PT. Bank SUMUT Syariah KCS. Padangsidimpuan, on July $17^{\text {th }}, 2018$

34 Interview with Pangasian (Marketing Officer), in PT. Bank SUMUT Syariah KCS. Padangsidimpuan, on July $27^{\text {th }}, 2018$

${ }^{35}$ Interview with Yusni (a society member), in PT. Bank SUMUT Syariah KCS. Padangsidimpuan, on July $16^{\text {th }}, 2018$
} 
Pedoman Akuntansi Perbankan Syariah Indonesia (PAPSI) Tahun 2003.

Slamet Wiyono, Cara Mudah Memahami Akuntansi Perbankan Syariah Berdasarkan PSAK dan PAPSI, Jakarta: PT. Grasindo, 2006.

Soejono Soekamto,Pengantar Penelitian Hukum, Jakarta: UI-Press, 1986.

Sutan Remy Sjahdeini, Perbankan Syariah :Produk-Produkdan Aspek Hukumnya, Jakarta: Kencana, 2014.

UU No. 21 Tahun 2008 Tentang Perbankan Syariah.

Veithzal Rivai, Bank and Financial Institution Management (Conventional dan Sharia System), Jakarta: PT. Raja Grafindo Persada, 2007.

Wiroso, Penghimpunan Dana \& Distribusi Hasil Usaha Bank Syariah, Jakarta: PT. Grasindo, 2005.

Wiroso, Produk Perbankan Syariah, Jakarta : LPFE Usakti, 2009.

www.ojk.go.id. 